\title{
MINERAL AND BIOACTIVE COMPOUND CONTENT IN PLANT-BASED PROTEIN - ENRICHED PUREES
}

\author{
Liene Ozola*, Solvita Kampuse \\ Department of Food Technology, Faculty of Food Technology, Latvia University of Life Sciences and Technologies, \\ Rigas iela 22, Jelgava, Latvia, e-mail: lieneozola8@inbox.lv
}

\begin{abstract}
Adequate, well balanced, diverse diet together with regular physical activity is considered to be the key elements for good health. The intake of macro and microelements has an important role in normal function of our bodies, ensuring enzymatic reactions, nerve impulses and other processes. However overly increased amounts of certain vitamins and minerals in the diet can be toxic. Therefore, the amount of certain nutrients needs to be consumed according to the age, gender and health condition. The aim of the research was to create new plant-based protein-enriched purees with increased protein amount, detect bioactive compound and mineral content and compare the mineral content with the recommended daily mineral intake for Latvians. For this research three recipes of new plant-based purees were created and experimentally made using organically grown ingredients from Latvia. Additional ingredients as whey-protein isolate, cod liver oil and sugar were added. Products were processed using cook-vide. All samples were tested on their mineral compound content ( $\mathrm{Na}, \mathrm{K}, \mathrm{Ca}, \mathrm{P}, \mathrm{Mg}, \mathrm{Fe}, \mathrm{Zn}, \mathrm{Cu}, \mathrm{Se}$ ), total carotene (TC) and total phenol content (TPC), antiradical activity (DPPH). The obtained data in all samples showed only trace amounts of Se per $100 \mathrm{~g}$ of product, on average the content of Na was only $1.2 \%$ from recommended daily intake (RDI) for Latvians per $100 \mathrm{~g}$ of product. The highest RDI was obtained for Fe in sample Sp1 for men $11.8 \%$, however for women only $7.1 \%$ of RDI. Overall the highest content of bioactive compounds was found in sample Sp2.
\end{abstract}

Keywords: total carotene, total phenols, DPPH, cook-vide

\section{Introduction}

The key role of sufficient nutrition is to provide living organisms with quantitatively and qualitatively appropriate nutrients to improve health, well-being and prevent from diseases (Cilla et al., 2018). Micronutrients are components that are needed for us in comparatively small amounts and include vitamins and minerals. Minerals are divided into major (macro) mineral compounds - $\mathrm{Ca}, \mathrm{Mg}, \mathrm{K}, \mathrm{Ma}, \mathrm{Cl}, \mathrm{P}, \mathrm{S}$ and trace (micro) minerals - I, Zn, Se, Fe, Mn, Cu, Co, Mo, F, Cr, B. These elements can be consumed by balanced nutrition of plant and animal sources (Mohammad et al., 2017).

Increased consumption of fruits and vegetables is recommended in dietary guidelines worldwide and fruits and berries are considered to be rich in nutrients and phytochemicals (Nile, Park, 2014).

Fruit and vegetable biochemical content differs depending on their variety and several environmental factors, however some similarities can be connected among the most widely found specimens of each particular crop.

Agricultural crops as beetroot, carrots and pumpkins are widely grown and used in Latvia. Beetroot (Beta vulgaris L.) can be a source of several minerals, for example $100 \mathrm{~g}$ of edible root part can contain $77 \mathrm{mg}$ of $\mathrm{Na}, 16 \mathrm{mg}-\mathrm{Ca}, 0.79 \mathrm{mg}-\mathrm{Fe}, 38 \mathrm{mg}-\mathrm{P}, 305 \mathrm{mg}-\mathrm{K}$, $23 \mathrm{mg}$ of $\mathrm{Mg}$ and $0.35 \mathrm{mg}$ of $\mathrm{Zn}$. Beetroot is also a source of highly active pigments - betalains and carotenoids, polyphenols and flavonoids, saponins, but some bioactive compounds found at low levels glycine, betaine and folate (Chhikara et al., 2019).

Consumption of carrots (Daucus carota L.) has increased in recent years due to their recognition as an important source of natural antioxidants, such as $\beta$-carotene, an average amount of $5.33 \mathrm{mg}$ per $100 \mathrm{~g}$ of fresh carrot. It is also a good source of mineral compounds, where $100 \mathrm{~g}$ on average can contain
$\mathrm{Ca}(34 \mathrm{mg}), \mathrm{Fe}(0.4 \mathrm{mg}), \mathrm{P}(25 \mathrm{mg}), \mathrm{Na}(40 \mathrm{mg})$, $\mathrm{K}(240 \mathrm{mg}), \mathrm{Mg}(9 \mathrm{mg}), \mathrm{Cu}(0.02 \mathrm{mg})$, and $\mathrm{Zn}(0.2 \mathrm{mg})$ (Sharma et al., 2012).

Pumpkins (Cucurbitaceae) have been traditionally eaten both by people and animals and it has several different varieties all with different chemical composition. But overall it is known to be a source of carotenoids, also vitamins like $\mathrm{K}$, several complex $\mathrm{B}$ vitamins as well as for minerals - K, P, Mg, Fe and $\mathrm{Se}$ (Ozola, Kampuse, 2018).

Jerusalem artichoke (Helianthus tuberosus) is an economically important plant with wide use of application both in food production and biofuel production in the world (Yang et al., 2015), however not as widely used in Latvia although grown here as long as potatoes. Overall as a crop Jerusalem artichoke has high yield and wide adaptation to climatic and soil conditions (Yang et al., 2015). The tubers on average contain $80 \%$ of water, $15 \%$ of carbohydrates and 1 to $2 \%$ of protein. Carbohydrates in cells are mostly stored in the form of inulin. Some research shows that boiled Jerusalem artichoke tubers contain $30 \mathrm{mg}$ of $\mathrm{Ca}, 0.4 \mathrm{mg}$ of $\mathrm{Fe}$, $420 \mathrm{mg}$ of K, $3 \mathrm{mg}$ of $\mathrm{Na}$ and also $20.0 \mu \mathrm{g}$ of carotenoids (Kays, Nottingham, 2007).

Apples are considered to be of moderate energy and nutritional value among common fruits, however they are consumed in rather large quantities therefore can have a significant contribution (Lee, 2012).

Berries are typically considered to be a good source of several vitamins and bioactive compounds as polyphenols, antioxidants, also minerals and fibres in various concentrations (Nile, Park, 2014).

Strawberries (Fragaria x ananassa) are one of the most popular and widely used berry for juicing due to its taste, rich essential nutrients, bioactive compounds, fibre, minerals and phenolic compounds. On average $100 \mathrm{~g}$ of strawberries contain $7.68 \mathrm{~g}$ of carbohydrate, $2.0 \mathrm{~g}$ of fibre and up to $4.89 \mathrm{~g}$ of sugar and $58.8 \mathrm{mg}$ of vitamin $\mathrm{C}$. 
$100 \mathrm{~g}$ of fruit can contain K (153 mg), P (24 mg), $\mathrm{Ca}$ (16 mg), Mg (13 mg) (Wang et al., 2018). Red raspberries (Rubus ideaus L.) are usually grown as perennial crop for their flavour and red colour. Much like previously described berries raspberry contains high levels of phenolic acids, flavonoids and also anthocyanins (Jin et al., 2012). Sea buckthorn (Hippophae rhamnoides L.) is also a very common in Europe, Asia and North America. Berries have high contents of vitamin $\mathrm{C}, \mathrm{E}$ and $\mathrm{K}$, carotenoids, flavanols and sugars, and are used in food industry, medicine, cosmetics (Lukša et al., 2018). But lingonberry is a berry from Nordic countries rich in polyphenols and vitamins C and E (Kivimäki et al., 2013). Some additional mineral composition of lingonberries, apples, pumpkin and red raspberries can be seen in Table 1 .

Table 1

Mineral content in lingonberry, raspberry, pumpkin and apple (DTU Fodevareinstituttet, 2019)

\begin{tabular}{lllll}
\hline $\begin{array}{l}\text { Minerals } \\
\text { per 100 g of } \\
\text { product }\end{array}$ & $\begin{array}{c}\text { Lingon- } \\
\text { berry }\end{array}$ & $\begin{array}{c}\text { Rasp- } \\
\text { berry }\end{array}$ & $\begin{array}{c}\text { Pump- } \\
\text { kin }\end{array}$ & Apple \\
\hline $\mathrm{Na}(\mathrm{mg})$ & 2.0 & 2.0 & 2.0 & 3.0 \\
$\mathrm{~K}(\mathrm{mg})$ & 89.0 & 228.0 & 243.0 & 120.0 \\
$\mathrm{Ca}(\mathrm{mg})$ & 20.0 & 19.7 & 20.1 & 3.9 \\
$\mathrm{P}(\mathrm{mg})$ & 16.0 & 38.0 & 33.0 & 17.4 \\
$\mathrm{Mg}(\mathrm{mg})$ & 9.0 & 17.0 & 11.2 & 4.4 \\
$\mathrm{Fe}(\mathrm{mg})$ & 0.40 & 0.55 & 0.27 & 0.12 \\
$\mathrm{Zn}(\mathrm{mg})$ & 0.18 & 0.34 & 0.20 & 0.03 \\
$\mathrm{Cu}(\mu \mathrm{g})$ & 0.07 & 0.11 & 0.08 & 0.03 \\
$\mathrm{Se}(\mu \mathrm{g})$ & 0.00 & 0.19 & - & 0.30 \\
\hline
\end{tabular}

Both bioactive compounds and minerals play an important role to maintain the basic functions of human body. Various bioactive compounds protect the body against diseases and disorders and the damaging effects of free radicals (Nile, Park, 2014), however minerals help to build strong bones and are a part for transmitting nerve impulses among many other functions (Mohammad et al., 2017).

A sufficient nutrition also means to maintain stable energy levels, this is especially important for people with regular increased physical activity such as athletes. However, no matter of what kind of physical activity each of us is doing, the most important thing is to eat different foods that can provide sufficient and regular energy intake of carbohydrates, proteins, fats and microelements (Potgieter, 2013). Products with increased protein content have become very popular with the athlete community. Protein consumption is necessary for muscle protein synthesis thus ensuring positive net muscle protein balance and for athletes engaged in resistance exercise can benefit from this with time by allowing muscle protein accretion and subsequent hypertrophy - growth of tissues or organs (Phillips et al., 2011). For this reason, in the last few years a growing interest in new product market has been noticed for well-balanced products and products, which are high in protein content. And sports nutritionists are more likely to develop individual nutrition plans depending on the needs of a single athlete and following a plan that athletes should consume diets that provide at least the recommended dietary allowance / adequate intake for all micronutrients (Nutrition and Athletic Performance, 2016).

Traditional cooking can lead to a loss of nutritional compounds and components responsible for flavour due to the required temperature and cooking time. Alternative cooking technologies such as vacuum treatments could help to decrease these losses (Iborra-Bernad et al., 2014; Ozola, Kampuse, 2017). The main advantage of vacuum cooking is the absence of oxygen that allows product cooking under $100{ }^{\circ} \mathrm{C}$ that is less harmful for thermolabile compounds (IborraBernad et al., 2014; Ozola, Kampuse, 2017). The most common vacuum treatment is sous-vide that allows product cooking inside heat-stable vacuumized pouches. However, in this research a different method, called cook-vide or vacuum boiling was used. Cook-vide is used to prepare products in hermetically closed cooking kettle by lowering pressure with continuous function of vacuum pump, that decreases the amount of oxygen in kettle and lowers pressure thus allowing to reach product / water boiling point below $100{ }^{\circ} \mathrm{C}$ (IborraBernad et al., 2014; Ozola, Kampuse, 2017).

For the purpose of this research the evaluated mineral compound content should ensure a minimum of $10 \%$ per compound of recommended daily mineral intake for Latvians per portion ( $200 \mathrm{~g})$ of created product.

The aim of the research was to create new plant-based protein-enriched purees with increased protein content, detect bioactive compound and mineral content and compare the mineral content with the recommended daily mineral compound intake for Latvians.

\section{Materials and Methods}

Three plant-based purees enriched with protein were developed. Most of the plant ingredients were grown organically in Latvia and industrially processed into semi-finished purees, juices or pulp juices. The plant material input in percent for each prepared sample is shown in Table 2. Additional ingredients were used in puree preparation: the main protein source - whey protein isolate in all samples (6\%), sugar (1\%) in samples Sp1 and Sp2, and cod liver oil $(0.5 \%)$ in all samples.

Table 2

Plant material input in recipes $(\%)$ of proteinenriched plant-based purees

\begin{tabular}{lccc}
\hline \multirow{2}{*}{ Ingredients } & \multicolumn{3}{c}{ Sample } \\
\cline { 2 - 4 } & Sp1 & Sp2 & Sp3 \\
\hline Sea buckthorn pulp juice & 5.0 & - & - \\
Apple puree & 25.5 & 12.0 & 24.5 \\
Carrot puree & 15.0 & 19.0 & - \\
Strawberry pulp juice & 13.0 & - & 13.0 \\
Jerusalem artichoke puree & 34.0 & - & - \\
Lingonberry pulp juice & - & 16.5 & - \\
Apple juice & - & 20.0 & - \\
Red beetroot puree & - & 25.0 & - \\
Red beetroot pulp juice & - & - & 12.0 \\
Pumpkin puree & - & - & 28.0 \\
Red raspberry pulp juice & - & - & 16.0 \\
\hline
\end{tabular}


Prepared recipes were vacuum cooked using cook-vide method at $0.06 \mathrm{MPa}$ pressure, with boiling temperature at $79 \pm 2{ }^{\circ} \mathrm{C}$ for $15 \mathrm{~min}$ followed by hot filling in glass jars and pasteurization in hot water bath at $95 \pm 2{ }^{\circ} \mathrm{C}$ for 20 min. Jars were cooled to room temperature in cold water $\left(7 \pm 3^{\circ} \mathrm{C}\right)$ for 1 hour and stored refrigerated till testing.

Samples were tested on their total protein amount and afterwards analysed on their content of total carotenes, total phenols, antiradical activity and mineral content.

Total protein content in samples were detected by Kjeldahl method according to ISO 20483:2013.

The content of total carotenes (TC) was detected by spectrophotometric method described by (ПолюдекФабини, Бейрих, 1981) and analysed using UV/VIS spectrophotometer Jenway 6705 (Bibby Scientific Ltd., $\mathrm{UK})$ at $440 \mathrm{~nm}$ and expressed as $\mathrm{mg} 100 \mathrm{~g}^{-1}$ per product (Ozola et al., 2017). Total phenol content (TPC) was detected according to the Folin-Ciocalteu method described by (Yu et al., 2003) with modifications, where to $0.5 \mathrm{~mL}$ of sample extract $2.5 \mathrm{~mL}$ of $0.2 \mathrm{~N}$ Folin-Ciocalteu reagent was added, after 5 minutes $2.0 \mathrm{~mL}$ of $7.5 \% \mathrm{NaCO}_{3}$ was added and the resulting solution was mixed and left to stand for 30 minutes at $18 \pm 1{ }^{\circ} \mathrm{C}$ in a dark place (Ozola et al., 2017) and shortly before reading absorption at $760 \mathrm{~nm}$ was centrifuged (ELMI Centrifuge CM-6MT, LTF Labortechnik $\mathrm{GmbH} \& \mathrm{Co}$, Germany) for 2 minutes at $3500 \mathrm{rpm}$. TPC was analysed using spectrophotometer JENWAY 6300 (Banworld Scientific Ltf., UK) and the obtained data were expressed as mg GAE $100 \mathrm{~g}^{-1}$ per product.

The antiradical activity (DPPH) was detected using 2,2-diphenil-1-picrylhydrazyl (DPPH) method described by Yu et al. ( 2003) with modifications where to $0.5 \mathrm{~mL}$ of extracted sample $3.5 \mathrm{~mL}$ of freshly made DPPH solution was added. The mixture was mixed and kept in the dark place at $18 \pm 2{ }^{\circ} \mathrm{C}$ for 30 minutes and centrifuged respectively to TPC detection and the absorbance was measured at $517 \mathrm{~nm}$ and the obtained data were expressed as $\mathrm{mM}$ TE $100 \mathrm{~mL}^{-1}$ of product (Ozola et al., 2017).

Samples were tested on their content of minerals such as $\mathrm{Na}, \mathrm{K}, \mathrm{Ca}, \mathrm{P}, \mathrm{Mg}, \mathrm{Fe}, \mathrm{Zn}, \mathrm{Cu}$, Se. The amount of $\mathrm{Ca}$, $\mathrm{Mg}, \mathrm{Fe}, \mathrm{Zn}, \mathrm{Cu}$ in tested samples was detected by Institue of Biology of University of Latvia using atomic absorption spectroscopy method, but the amount of K and $\mathrm{Na}$ detected by flame photometer Jenway PFP7 (Cole-Parmer, UK) and content of $\mathrm{P}$ was detected calorimetrically with ammonium molybdate. The amount of Se in samples was detected by Institute of Food Safety, Animal Health and Environment (BIOR) and their standardised BIOR-T-012-148-2013 method. The amount of minerals was expressed in $\mathrm{mg} \mathrm{kg}^{-1}$ per dry sample, but recalculated to $\mathrm{mg} 100 \mathrm{~g}^{-1}$ per product. Total protein content, TC, TPC and antiradical scavenging activity was measured in three repetitions, but mineral content was determined in single repetition. Statistical analysis was done using 'Microsoft Office Excel' 2007 version. Differences between the obtained results on bioactive compound content were analysed using ANOVA: Single factor analysis with TukeyKramer post hoc test. The data is presented as their mean and differences among results were considered to be significant if $\mathrm{p}$ value $<\alpha_{0.05}$.

\section{Results and Discussion}

The average total protein content in all samples ranged from 6.2 to $6.5 \mathrm{~g}$ per $100 \mathrm{~g}$ of sample. Sample Sp1

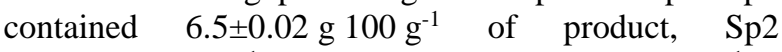

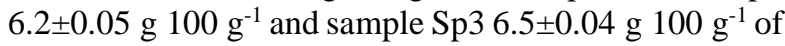
product. These amounts are comparable to the expectations during sample preparation, due to the fact that majority of the used ingredient total protein content did not exceed $1 \mathrm{~g}$ per $100 \mathrm{~g}$ of sample (DTU Fodevareinstituttet, 2019). Also, the obtained protein content was appropriate for this type of product, as the average protein intake for adults should not exceed $10-20 \%$ of daily caloric value according to recommended energy and nutrient intakes for Latvian residents. These directions foresee ca. $75 \mathrm{~g}$ protein intake for adults on a $2000 \mathrm{kcal}$ diet (Ieteicamās energijas un uzturvielu devas Latvijas iedzīvotājiem, 2017), in addition to the prepared purees are used as supplements to nutrition.

The obtained data on the prepared sample bioactive compound content showed some differences. Evaluation of the data on total carotene content (Fig. 1.) showed that sample Sp3 had by around $40 \%$ lower content of total carotenes than sample $\mathrm{Sp} 2$, which is a significant difference according to Tukey-Kramer post hoc test.

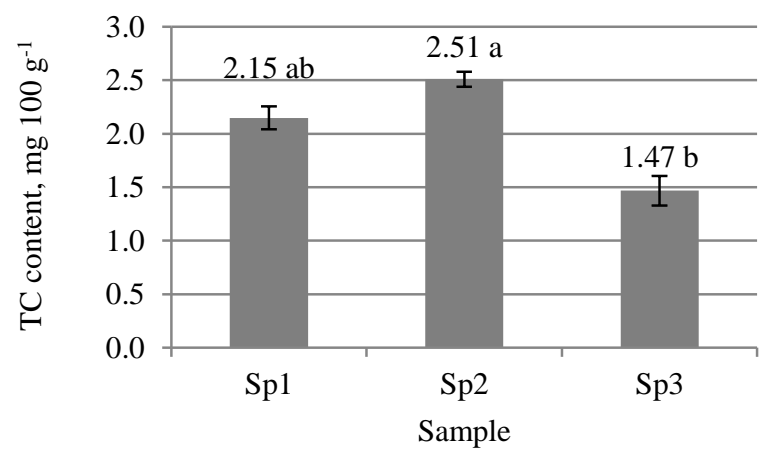

Figure 1. Total carotene content in prepared plant-based purees

Different letters indicate a significant difference in the mean at $\mathrm{p}<0.05$ according to Tukey-Kramer test.

Differences between samples Sp1 and Sp2 were not as significant to be considered relevant in this case. The difference was only $14 \%$. These results are directly influenced by the sample ingredient content, where samples Sp1 and Sp2 contained carrot as the major carotene source and also sea buckthorn in Sp1. The highest content of total phenols was also detected in sample Sp2 (Fig.2), however, contrary to TC content, sample Sp1 had 20\% lower TPC, therefore significant differences between these samples were noticed.

Although TC and TPC showed some differences between separate samples, no such data was noticed after antiradical activity evaluation. 


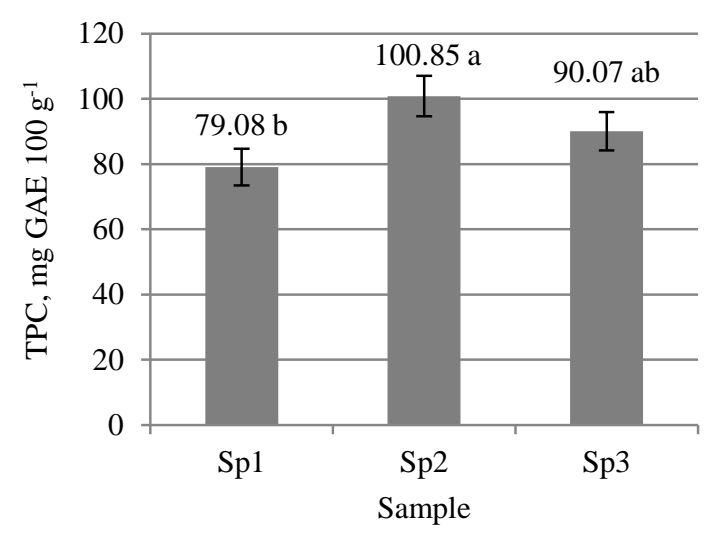

Figure 2. Total phenol content in prepared plantbased purees

Different letters indicate a significant difference in the mean at $\mathrm{p}<0.05$ according to Tukey-Kramer test.

Similarly, to previous observations, sample $\mathrm{Sp} 2$ also showed slightly higher antiradical activity (Fig.3) compared to other samples. In comparison a research on high-pressure processed smoothies containing orange juice, papaya juice, melon juice, carrot puree and skimmed milk (Andrés et al., 2016), showed a total carotenoid content of $20.43 \pm 0.47 \mathrm{mg} 100 \mathrm{~mL}^{-1}$ in thermally processed $\left(80^{\circ} \mathrm{C}, 3 \mathrm{~min}\right)$ samples.

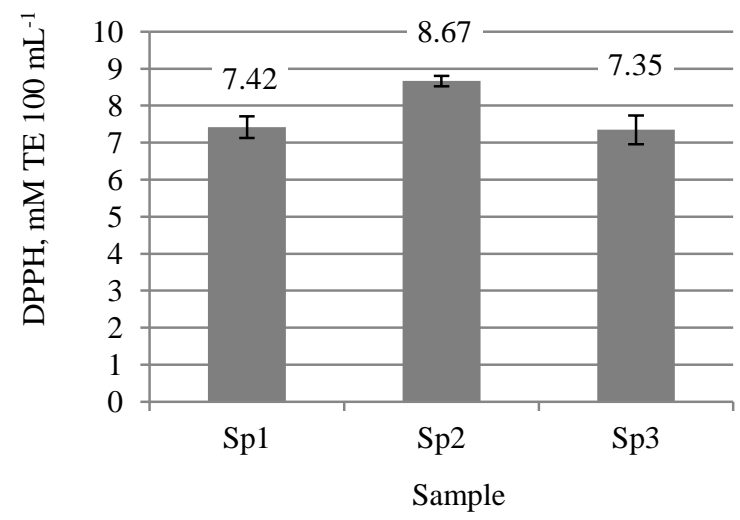

Figure 3. Antiradical activity in prepared plantbased purees

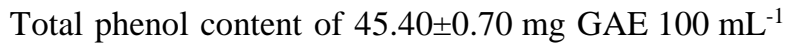
and DPPH $53.9 \pm 0.7 \mathrm{mM}$ TE $100 \mathrm{~mL}^{-1}$ with a gradual bioactive compound deterioration during 45 day refrigerated storage period was also established (Andrés et al., 2016). Overall, plant-based puree samples showed higher total carotene and antiradical activity levels, but did not exceed total phenol content. These results could suggest that plant-based purees made for this research contain different phenol compounds in rather high concentrations due to variety of berry juices used in the sample preparation. However, they do not have strong antiradical activity, which could shorten the shelf life of these products.

The data from mineral compound content (Table 3) analysis showed only trace amounts of $\operatorname{Se}\left(<0.20 \mathrm{mg} \mathrm{kg}^{-1}\right)$ present, levels were not high enough for precise amount declaration in prepared samples. This information does coincide with typical sources of Se nutritionally provided by intake of organ meats, cereals and other grains, dairy products, rice, sea food, eggs and other similar products (Selenium, 2018). Other tested mineral compounds were detected in higher and more substantial amounts.

Table 3

Mineral content in experimental samples and average RDI of minerals in Latvia (mg)

\begin{tabular}{|c|c|c|c|c|}
\hline \multirow{2}{*}{ Minerals } & \multicolumn{3}{|c|}{ Sample (mg $\left.100 \mathrm{~g}^{-1}\right)$} & \multirow{2}{*}{ RDI $^{*}$} \\
\hline & Sp1 & Sp2 & Sp3 & \\
\hline K & 230.5 & 180.9 & 213.1 & $\begin{array}{l}3500(\mathrm{~m}) \\
3100(\mathrm{w})\end{array}$ \\
\hline $\mathrm{Ca}$ & 40.3 & 36.6 & 36.6 & 800 \\
\hline $\mathrm{P}$ & 34.5 & 25.6 & 39.5 & 600 \\
\hline $\mathrm{Mg}$ & 18.5 & 17.1 & 23.2 & $\begin{array}{l}350(\mathrm{~m}) \\
280(\mathrm{w})\end{array}$ \\
\hline $\mathrm{Fe}$ & 1.1 & 0.4 & 0.4 & $\begin{array}{l}9(\mathrm{~m}) \\
15(\mathrm{w})\end{array}$ \\
\hline $\mathrm{Zn}$ & 0.2 & 0.2 & 0.2 & $\begin{array}{l}9(\mathrm{~m}) \\
7(\mathrm{w})\end{array}$ \\
\hline $\mathrm{Cu}$ & 0.1 & 0.1 & 0.1 & 0.9 \\
\hline $\mathrm{Na}$ & 25.4 & 28.2 & 21.2 & 2000 \\
\hline
\end{tabular}

RDI - average values of recommended daily mineral compound intakes for adults, $\mathrm{m}$ - adult men, $\mathrm{w}$ - adult women

According to the recommended energy and nutrient intakes for Latvian residents (Ieteicamās energijas un uzturvielu devas Latvijas iedzīvotājiem, 2017) the prepared plant-based protein-enriched purees with increased protein content showed that $100 \mathrm{~g}$ of sample Sp1 can provide a potassium daily intake of $7.4 \%$ for women and $6.6 \%$ for men and 5\% of RDI of Ca. Sample Sp1 also showed a comparatively higher amount of iron, which is comparable to $7.1 \%$ of RDI for women and $11.8 \%$ for men, these amounts are approximately $60 \%$ higher than in sample Sp2 and Sp3. Sp1 contains 9.7\% of $\mathrm{RDI}$ of $\mathrm{Cu}$ for both genders. Between the three experimental samples mineral compounds such as $\mathrm{P}, \mathrm{Mg}$ and $\mathrm{Zn}$ were found to be in higher amounts in sample Sp3 than in other samples. The detected amount of $\mathrm{Mg}$ in $\mathrm{Sp} 3$ could possibly provide $8.3 \%$ of RDI for women and $6.6 \%$ of nutritional needs for men. This sample also provides the lowest amount of $\mathrm{Na}$, approximately $1.1 \%$ of RDI, which is about $24 \%$ less than in sample Sp2.

Although the evaluation of some bioactive compounds overall showed higher amounts of total carotenes, phenols and antiradical activity in sample $\mathrm{Sp} 2$, the content of mineral compounds was relatively low

\section{Conclusions}

The chosen ingredients for sample preparation were able to ensure an appropriate amount of some mineral compounds per $200 \mathrm{~g}$ serving. However, it would be advisable to search for plant-based products with higher concentrations of selenium or adding a selenium complex to ensure partial coverage of recommended daily intake.

Also, low levels of zinc were detected in all samples, on average ensuring $4 \%$ of RDI per serving. 
Sample Sp2 containing apple puree, carrot puree, lingonberry pulp juice, apple juice, red beetroot puree, overall had the lowest mineral compound coverage of RDI. The $10 \%$ margin per sample serving of mineral compounds was met by content of potassium $(\mathrm{K})$ and copper $(\mathrm{Cu})$ for both men and women, and of magnesium $(\mathrm{Mg})$ for men.

The evaluation of bioactive compound content did not show substantial differences between the samples, slightly larger differences in content of total carotene were detected between samples Sp2 (apple puree, carrot puree, lingonberry pulp juice, apple juice, red beetroot puree) and Sp3 (apple puree, strawberry pulp juice, red beetroot juice, pumpkin puree, red raspberry pulp juice).

\section{Acknowledgment}

This research was supported by program 'Scientific Capacity Building at LLU' project A05-06 'Development of special dietary foods with high bioavailability'

\section{References}

1. Andrés V., Villanueva M. J., Tenorio M. D. (2016) The effect of high-pressure processing on colour, bioactive compounds, and antioxidant activity in smoothies during refrigerated storage. Food Chemistry, Vol. 192, p. $328-335$.

2. Chhikara N., Kushwaha K., Sharma P., Gat Y., Panghal A. (2019) Bioactive compounds of beetroot and utilization in food processing industry: A critical review. Food Chemistry, Vol. 272, p. 192-200.

3. Cilla A., Bosch L., Barberá R., Alegría A. (2018) Effect of processing on the bioaccessibility of bioactive compounds - A review focusing on carotenoids, minerals, ascorbic acid, tocopherols and polyphenols. Journal of Food Composition and Analysis, Vol. 68, p. 3-15.

4. DTU Fodevareinstituttet. (2019) [accessed on 11.02.2019]. Available at: https://frida. fooddata.dk/?lang=en

5. Iborra-Bernad C., Tárrega A., García-Segovia P., Martínez-Monzó J. (2014) Comparison of vacuum treatments and traditional cooking using instrumental and sensory analysis. Food Analytical Methods, Vol.7(2), p. $400-408$.

6. Ieteicamās enerǵijas un uzturvielu devas Latvijas iedzīvotājiem (2017) [accessed on 11.022019]. Available at: http://www.vm.gov.lv/images/userfiles/Tava veseliba/Ieteicamās_enerğijas_un_uzturvielu_devas.pdf

7. ISO 20483:2013 - Cereals and pulses - Determination of the nitrogen content and calculation of the crude protein content - Kjeldahl method. [accessed on 31.01.2019] Available at: https://www.iso.org/standard/59162.html

8. Jin P., Wang Y., Gao H., Chen H., Zheng Y., Wang C. Y. (2012) Effect of cultural system and essential oil treatment on antioxidant capacity in raspberries. Food Chemistry, Vol. 132, p. 399-405.

9. Kays S. J., Nottingham S. F. (2007) In: Biology and Chemistry of Jerusalem Artichoke Helianthus tuberosus $L$. Chemical Composition and Inulin Chemistry. CRC Press, Taylor \& Francis Group, p. 53-96.

10. Kivimäki A. S., Siltari A., Ehlers P. I., Korpela R., Vapaatalo H. (2013) Lingonberry juice lowers blood pressure of spontaneously hypertensive rats (SHR).
Journal of Functional Foods, Vol. 5(3), p. 1432-1440.

11. Lee C. Y. (2012) Common nutrients and nutraceutical quality of apples. New York Fruit Quarterly, Vol. 20(3), p. 8-8.

12. Lukša J., Vepštaitė-Monstavičè I., Yurchenko V., Serva S., Servienè, E. (2018) High content analysis of sea buckthorn, black chokeberry, red and white currants microbiota - A pilot study. Food Research International, Vol. 111, p. 597-606.

13. Mohammad S., Gharibzahedi T., Jafari S. M. (2017) The importance of minerals in human nutrition: Bioavailability, food fortification, processing effects and nanoencapsulation. Trends in Food Science \& Technology, Vol. 62, p. 119-132.

14. Nile S. H., Park S. W. (2014) Edible berries: Bioactive components and their effect on human health. Nutrition, Vol. 30(2), p. 134-144.

15. Nutrition and Athletic Performance (2016) Medicine \& Science in Sports \& Exercise, Vol. 48(3), p. 543-568.

16. Ozola L., Kampuse S. (2017) The effect of vacuum cooking on enteral food made from fresh and semifinished ingredients. In: Research for Rural Development, Vol. 1, p. 208-214.

17. Ozola L., Kampuse S. (2018) Influence of heat treatment methods on bioactive compound concentrations in pumpkin-guelder rose (Viburnum opulus) sauces. Proceedings of the Latvian Academy of Sciences. Section B. Natural, Exact, and Applied Sciences, Vol. 72(2), p. $97-102$.

18. Ozola L., Kampuse S., Galoburda R. (2017) The effect of high-pressure processing on enteral food made from fresh or semi-finished ingredients. In: 11th Baltic Conference on Food Science and Technology, p. 80-85.

19. Phillips S. M., Luc, Van Loon J. C. (2011) Dietary protein for athletes: From requirements to optimum adaptation. Journal of Sports Sciences, Vol. 29(1), p. 29-38.

20. Potgieter S. (2013) Sport nutrition: A review of the latest guidelines for exercise and sport nutrition from the American College of Sport Nutrition, the International Olympic Committee and the International Society for Sports Nutrition. South Africa Journal of Clinical Nutrition, Vol. 26(1), p. 6-16.

21. Selenium. (2018) [accessed 06.02.2019] Available: from https://ods.od.nih.gov/factsheets/Selenium-

HealthProfessional/

22. Sharma K. D., Karki S., Thakur N. S., Attri S. (2012) Chemical composition, functional properties and processing of carrot-a review. Journal of Food Science and Technology, Vol. 49(1), p.22-32.

23. Wang J., Wang J., Ye J., Kranthi Vanga S., Raghavan V. (2018) Influence of high-intensity ultrasound on bioactive compounds of strawberry juice: Profiles of ascorbic acid, phenolics, antioxidant activity and microstructure. Food Control, Vol. 96, p.128-136.

24. Yang L., He Q. S., Corscadden K., Udenigwe C. C. (2015) The prospects of Jerusalem artichoke in functional food ingredients and bioenergy production. Biotechnology Reports, Vol. 5(1), p. 77-88.

25. Yu L., Perret J., Harris M., Wilson J., Haley S. (2003) Antioxidant properties of bran extracts from "Akron" wheat grown at different locations. Journal of Agricultural and Food Chemistry, Vol. 51(6), p. 1566-1570.

26. Полюдек-Фабини Р., Бейрих Т. (1981) Органический анализ. В: Химия (р. 499-500). Ленинград. 